https://helda.helsinki.fi

\title{
Otherness and Difference : On the Cultural Logic of Racial Tolerance
}

\section{Minkkinen, Panu}

1992

Minkkinen , P 1992 , ' Otherness and Difference : On the Cultural Logic of Racial Tolerance ' , Law and Critique, vol. 3 , no. 2 , pp. 147-167.

http://hdl.handle.net/10138/33888

publishedVersion

Downloaded from Helda, University of Helsinki institutional repository.

This is an electronic reprint of the original article.

This reprint may differ from the original in pagination and typographic detail.

Please cite the original version. 


\section{OTHERNESS AND DIFFERENCE: \\ ON THE CULTURAL LOGIC OF RACIAL TOLERANCE}

by

PANU MINKKINEN*

\section{The Other and Cultural Identity}

As a political and social phenomenon, racist violence has recently become commonly associated with the disquieting re-emergence of populist nationalism and neo-fascism in Europe. Young adherents of the British National Front, frequently identified as "skinheads", have been responsible for violent attacks against Asian and West African minorities. In France, similar hostility of racist nature as well as the persecution of the Jewish population have been more or less openly supported by M. Jean-Marie le Pen, leader of the local extreme-right party. German youth gangs, often originating from the economically deprived former eastern parts of the country, have been accused of harassing immigrant workers of Turkish and North African origin. Individual occurrences faithfully mimic an elementary structure: youth gangs with explicit or supposed neo-fascist sympathies and racially motivated violence.

Racist violence has, naturally, always been a central issue of critical jurisprudence. It is a social problem, and in a modern welfare state, law is first and foremost conceived of as a means to an end, as a just remedy to an annoying disease. But despite its violent nature and its alarming political implications, the core of the problem does not seem to be the spectacular nature of contemporary racism. Quite the contrary, racism has become banal, worldly, matter of fact, a normal phenomenon. The myriad of racist images has, indeed, "seduced" the referent, made racism itself disappear. But a form of normalization is quite evident in the legal sphere proper, as well. Racism is not the "evil" it once was. The logic of welfare state legislation has relativized racism into a social problem among others.

* University of Helsinki, Finland. 
François Ewald has proficiently depicted the characteristics of welfare state legislation in his conception of social law. ${ }^{1}$ Social law resolves disputes through legal settlements, not by differentiating between the right and the wrong. The government of racism through social law would suggest, firstly, that the conflicting parties are already in a mutually obliging contractual relationship. A legal evaluation of racism in the welfare state would mean that racial violence is a "breach of contract", violating the terms of an agreement of peaceful co-existence. The co-existence of races is, therefore, based on a contract presupposed to be mutually profitable. Secondly, government through social law objectifies racism into a conflictual social order that promotes the well-being of society as a whole. In this context, Ewald specifically mentions Augustin Thierry's doctrine of race war as a primus motor of historical progress. In this conflictual order, all parties possess rights, and conflicting rights are balanced through proper government. Racist violence is, accordingly, a necessary ingredient of social progress. Thirdly, the legal settlement conceived by social law requires solidarity and concessions from both parties of the conflict. This calls for compromises vis-à-vis "absolute rights" as well as mutual tolerance. In the resolution of racial conflicts, all involved parties are sympathized. Legitimate grounds can be found for the actions of both parties, and this tolerance is understood as the credo of the welfare state and its social law:

...on ne doit pas seulement tolérer la différence, l'altérité, l'égale valeur de l'autre, mais, à son profit, la limite de son droit. Le droit social est symbolique d'une société de masse où, parce que l'espace viendrait à manquer, chacun devrait apprendre à supporter l'autre et ses inéluctables empiètements.

[...what has to be tolerated is not only the difference, the otherness, the equal value of the other, but even, for our benefit, the restriction of our right. Social law is symbolic of a mass society in which, because space is running short, each must learn to put up with the other and his unavoidable encroachments. $]^{2}$

1 François Ewald, L'État providence (Paris: Grasset, 1986), 457-468. In English, this section of the book has been published as "A Concept of Social Law", in Gunther Teubner (ed.), Dilemmas of Law in the Welfare State (Berlin/New York: De Gruyter, 1986), 40-74.

2 Ewald, L'Etat, supra n.1, at 462; Ewald, “Concept”, supra n.1, at 49. 
Europe has unfortunately learned to live with her racism or, to be more exact, she has never learned to live without it. This normality of racism presents the law with a problem: how does one regulate racism? How can the normative penetrate into the normal?

Coinciding with the normalized racist violence described above, a new variant of racial tolerance, less overtly political than the critique of racism of the decades before, has taken shape. This new variant is founded on the ideal of the "global village", and its discursive elements are present in, for example, the ecological emphases of the "green" ideology and in the wide interest concerning different manifestations of world culture. Perhaps campaigning for rain forests or praising third world culture cannot be accounted for as explicit critique of racism, but the essential notion of racial esteem is, no doubt, present.

Occidental racial thought has seldom been analyzed by way of its enlightened half, and yet, most attempts to confront racism as a social problem must necessarily be based on some conception of racial esteem. It would seem, then, that the opponents of racism do not know what they are doing or, more accurately, how they are doing it. The ideal of the global village is, of course, only one variant of racial esteem among others. The common denominator uniting different variants of racial thought is the opposition intolerance/tolerance, the self-ironical etymology tolerare connoting, on the one hand, that Occidental racial respect has always been a matter of enduring, of "putting up with differences" 3 and, on the other hand, that Occidental racial debate is often of a rather tempered nature. A racial debate implies a biological meta-logic, a science of the physical and intellectual qualities of the different races: racism is always a discourse on the superiority of the subject while the critique of racism denies the validity of racial biology in general. Yet both racism and its tolerating opposition require a language, a cultural logic. In other words, the bio-logic of racial discourse, its logos of life, is the language it speaks. In one of his few explicitly political texts, Jacques Derrida outlines the logos of race:

Pas de racisme sans une langue. Les violences raciales, ce ne sont pas seulements des mots, mais il leur faut un mot. Bien qu'il allègue le sang, la couleur, la naissance, ou plutôt parce qu'il tient ce discours

3 Ewald seems to reserve the attribute of tolerance exclusively for the welfare state. See Ewald, L'Etat, supra n.1, at 488-489. 
naturaliste et parfois créationniste, le racisme trahit toujours la perversion d'un homme "animal parlant". Il institue, déclare, écrit, inscrit, prescrit. Système de marques, il dessine des lieux pour assigner à résidence ou fermer des frontières. Il ne discerne pas, il discrimine.

[... there's no racism without a language. The point is not that acts of racial violence are only words but rather that they have to have a word. Even though it offers the excuse of blood, color, birth - or, rather, because it uses this naturalist and sometimes creationist discourse racism always betrays the perversion of man, the "talking animal". It institutes, declares, writes, inscribes, prescribes. A system of marks, it outlines space in order to assign forced residence or to close off borders. It does not discern, it discriminates. $]^{4}$

Racial thought - be it intolerance or tolerance - is inscribed into the language of race through a conception of cultural identity. In cultural identity, the Occidental subject brings itself into contact with a foreign culture or its representative. As it is uttering "I am this", the subject must necessarily also affirm that "I am not that, I am not the other". In the metaphor of race, the foreignness of the other is concentrated. A different race presupposes numerous other differences as well, and since race is a very stable characteristic, it keeps the other at a safe distance. The observation of a foreign culture requires the subject to "objectify" the other beyond itself, to perform a distinction between itself and its other. Reflecting on the other through and in itself, the subject can acquire a sense of identity, define the limits of a cultural terrain where the subject can be "what it is." 5

This structure of identity that can be traced from most manifestations of Occidental ethnocentricity is as old as Occidental culture itself. It is, however, a relatively weak version of discriminatory thought. Its structure is still fluid, lacking the constancy and unconditional character of racism. The barbaros of Homeric Greece

4 Jacques Derrida, "Le dernier mot du racisme", in Psyché. Inventions de l'autre (Paris: Galilée, 1987), 353-362, quotation at 355. English translation, "Racism's Last Word", Critical Inquiry 12 (Autumn 1985), 290299, quotation at 292.

5 In his textbook on legal anthropology, Norbert Rouland defines anthropology as a discourse on otherness and maintains that structuring the world as a relationship between the viewing subject and an object under observation is primarily an Occidental characteristic. Norbert Rouland, Anthropologie juridique (Paris: Presses Universitaires de France, 1988), 25-40. 
could still challenge Hellenic supremacy by refining his accent. Ethnocentricity is open: the centre can always be redefined, the alleged boundaries of the periphery redrawn. Intolerance in the form of racism and overt discrimination, on the other hand, thrives on a stigma, a permanent stain. It requires that the superiority of the subject vis-à-vis the other is fixated into a structure with mandatory power, a law (nomos) or a name (nomen). ${ }^{6}$ This structure reduces abstract identity into individuality by prescribing the subject a privileged position, by transforming it into a person.

In Latin, the etymology of the word person $a^{7}$ refers to per sonare, "with a mask". In Roman society, the persona was originally a character in a dramatic presentation, a personage acted out in a theatrical mask. The mask was also of social significance in the various religious rites performed by the families of Roman society. Certain members of society were entitled to take part actively in the rites by using specific masks. The ritualistic characters displayed with the masks included corresponding names, and the entitled users of the masks eventually attained a right to use this name. The ritualistic right to use a name was later handed down to the next generation of the family. Thus the name developed into a legal privilege of the family, distinguishing it in a permanent fashion from the nonprivileged.

As non-human and inanimate objects of property, slaves were deprived of names altogether. On the other hand, the privilege of using the sacred name of the gens was restricted to only certain patrician families, and it also marked the dividing line between Roman citizens and free individuals of foreign origin. In the Senate, the pater of the privileged gens was a persona with the right to use the corresponding name of his family. However, as a persona, he did not only represent himself but also the continuity of his family, his ancestry and his posterity. The persona was a representation rather than a representative, a simulacrum of someone else, of the other.

6 The genealogical kinship of nomos and nomen has been noted in, e.g., Carl Schmitt, Der Nomos der Erde im Völkerrecht des Jus Publicum Europaeum (Köln: Greven Verlag, 1950).

7 On persona and name, see Marcel Mauss, "Une catégorie de l'esprit humain: La notion de personne, celle de "Moi'", in Anthropologie et sociologie (Paris: Presses Universitaires de France, 1950), 331-362. 
This dual characteristic of the persona and the corresponding name, that is, the capacity to possess a subjective right and the representational relationship between the subject and the other, also depicts Occidental ethnocentrism in its fixated structure. Racism as intolerance defines the subject as a fixed privilege or right and the other as a representation of the subject. But since tolerance is always reflected against intolerance, it must accordingly project the same structural elements. The evaluative outcome is, of course, very different.

\section{The Scientist and the Rule of Tolerance}

A primary variant of racial tolerance can be called tropism, ${ }^{8}$ namely, a scientific axiology ${ }^{9}$ based on the ideal of cultural pluralism. Prior to the emergence of cultural pluralism, the racial signs that established the supremacy of the European race and its culture were protected by an unconditional principle. Distinctions between races were made by referring to racial origins as if they constituted a global caste system with its visible marks of hierarchy. The distinctive sign, namely, race and colour, was protected by a cultural patent: all manifestations of sophistication and progress in the

8 In the theory of the nouveau roman, tropism is a term introduced by Nathalie Sarraute indicating that the subject displays its true position vis-à-vis the other rather through delicate inner movements than through outward communicative intentions. Nathalie Sarraute, Tropismes (Paris: Éditions du Minuit, 1957). In the foreword of an English translation, Sarraute writes of her choice of concept: "These movements, of which we are hardly cognizant, slip through us on the frontiers of consciousness in the form of undefinable, extremely rapid sensations. They hide behind our gestures, beneath the words we speak and the feelings we manifest... I gave them this name because of their spontaneous, irresistible, instinctive nature, similar to that of the movements made by certain living organisms under the influence of outside stimuli ... [tropisms] are produced in us by the presence of others ..." Nathalie Sarraute, Tropisms and The Age of Suspicion (London: John Calder, 1963), 8-9.

9 In his book on colonialism, Todorov defines axiology as an evaluative comparison between races. See Tzvetan Todorov, La conquête de l'Amerique. La question de l'autre (Paris: Éditions du Seuil, 1982). On racism, see also Tzvetan Todorov, Nous et les autres. La réflexion française sur la diversité humaine (Paris: Éditions du Seuil, 1989). 
other race were deemed illegal and void. Outlawed from cultural recognition, the other race could never challenge the supremacy of the European subject.

It is ethnological and anthropological science and its ideal of pluralism that first breaks the racist spell and establishes a new relativity that can be interpreted as racial tolerance. The same tropistic tolerance is still present in the writing of Claude LéviStrauss. ${ }^{10}$ In a text entitled "Race et histoire" from 1952,11 LéviStrauss affirms that cultural pluralism is the dynamic force of the anthropological knowledge he represents. The diversity of cultures is a challenge to the monotony of racist prejudices which are unable to account for human phenomena: the diversity and richness of cultures cannot be explained with a biological interpretation of race. ${ }^{12}$

In Lévi-Strauss' tropism, the relationship between the subject of science and the other race is an analogy: the other race and its cultural achievements must simultaneously resemble the subject and possess singular and distinctive traits which can be observed to satisfy the scientific subject's tolerant curiosity. Lévi-Strauss' text recognizes the ethnocentric quality of the analogy ${ }^{13}$ but cannot avoid the analogy itself. The tolerance displayed in the text, "a sentiment of gratitude and humility", is inspired by a single "conviction", a tolerant faith: "... c'est que les autres cultures sont différentes de la sienne, de la façon la plus variée ... [ ... that the other cultures differ from his own in the most varied manner ..."14 The analogical relationship between the races is established by the conviction that the other race must always be different in comparison to the subject. But convictions and faiths such as tolerance are always tempted by

10 Derrida's critique of Lévi-Strauss seems to touch upon the theme of racial tolerance. See Jacques Derrida, De la grammatologie (Paris: Editions du Minuit, 1967), 145-202. Would it be, then, more or less justified to call Lévi-Strauss' ethnological naïveté tristes tropismes, "clumsy pathos"?

11 Claude Lévi-Strauss, "Race et histoire" in Anthropologie structurale deux (Paris: Plon, 1973), 377-422 (hereafter AS). English translation, "Race and History" in Structural Anthropology Volume 2 (Chicago: The University of Chicago Press, 1976), 323-362 (hereafter SA).

12 AS, 377-379; SA, 323-325.

13 AS, 395-397; SA, 339-340.

14 AS, 417 [emphasis added]; SA, 358. 
heretical beliefs. Lévi-Strauss' text names the heresy as false evolutionism or cultural Darwinism. As a mode of intolerance, the heresy attempts to try out the tolerant faith, to annul the diversity of human cultures with pretences of absolute knowledge. ${ }^{15}$ As a devout believer, the subject of science can never know everything. The other race must remain simultaneously familiar and foreign, recognizable and mysterious. It would be an indication of intolerance to annihilate scientific enterprise and tolerant curiosity by knowing too much, by proceeding from partial to inclusive analogy.

Le procédé consiste donc à prendre la partie pour le tout, à conclure, du fait que certains aspects de deux civilisations ... offrent des ressemblances, à l'analogie de tous aspects. IThe process consists in taking the part for the whole, concluding - because some aspects of both ... civilizations present similarities - with the analogy of all their aspects. $]^{16}$

Tropism is a textual movement involving a reading of signs suitable for the analogical evaluation of races, and the success of an acceptable evaluation requires that the racial signs are liberated from the pre-scientific unconditional principle. The liberty of cultural pluralism does not, however, mean new interpretations of given or predetermined signs, of the old caste marks. Tropism is movement within an open structure with a luxurious surplus of signifying elements. In answer to the intellectual demand induced by the subject's tolerant curiosity, scientific activity must be able to read new signs that make a tolerant evaluation between the races possible. The overwhelming plurality of readable signs is also evident in LéviStrauss' text. Races are rarely isolated internally or externally and, accordingly, the text confirms that diversity is not static. It cannot be reduced into a comprehensive inventory of distinctive signs. ${ }^{17}$ Quite the contrary, diversity is always much richer than the scientific subject's capacity to comprehend, ${ }^{18}$ and the extent of cultural differences can only be grasped in an incomplete manner. ${ }^{19}$ Tropism is, therefore, a generative reading of new signifying elements, a

15 AS, 385; SA, 330.

16 AS, 388; SA, 333.

17 AS, 381-382; SA, 327-328.

18 AS, 380; SA, 326.

19 AS, 417; SA, 358. 
production of cultural differences, movement within an open structure of superfluous distinctive signs.

In an analogical relationship, the subject considers the other race as a fascinating imitation of natural characteristics, a facsimile that feigns the laws of nature. Nature is, then, the axiological scale on which the imitation and the original are distinguishable. LéviStrauss' text does not explicitly identify nature, but it does name three categories of culture: the temporally proximate and spatially distant, the temporally distant and spatially proximate, and the temporally and spatially distant. ${ }^{20}$ The remaining category, i.e., the temporally and spatially proximate, the here and now - LéviStrauss himself - must accordingly stand for something other than culture, for nature.

The text condemns racial intolerance both as malevolent exclusion and benevolent inclusion, as rejection from humanity and interjection eliminating diversities. ${ }^{21}$ On the other hand, tropism itself can express tolerance only by disregarding differences - something which has already been deemed intolerant - and focusing on cultural values that are approximately the same for all men: language, technique, art, knowledge, belief and social, economic and political organization. ${ }^{22}$ Yet, it is obvious that tropism, as it is portrayed in the text, can only be formulated through Lévi-Strauss' own natural language, technique, knowledge and beliefs. Tropism is a mode of racial existence, and as soon as the scientific subject turns its inspecting gaze on the observed diversities, the existence of the other race is necessarily defined by way of the subject and its status as nature.

As in any variant of racial tolerance, the anti-racist principle regulating racial thought in tropism follows a specific normative logic: the logic of a rule. This logic is particularly evident in LéviStrauss' frequent metaphoric allusions to tropism as a game. ${ }^{23}$ Intolerance as the inability to read signs of progress in so called "primitive" societies is a result of defining the rules of the scientific game in an inappropriate way. Intolerance is playing at un-

20 AS, 387; SA, 332.

21 AS, 383-385; SA, 328-329.

22 AS, 401; SA, 344.

23 On Lévi-Strauss and the game, see Jacques Derrida, "La structure, le signe et le jeu dans le discours des sciences humaines", in L'Écriture et la différence (Paris: Éditions du Seuil, 1967), 409. 
favourable odds in a game with "contributions" to be won. The text promotes tolerance as playing collectively in order to improve the chances of winning. ${ }^{24}$ On the other hand, the text defines tolerance as giving recognition to the contributions of the other race to the common patrimony. ${ }^{25}$ But this does not mean the comprehensive listing or cataloguing of particular contributions into the estate, it is not a legally governed balancing of accounts. The contribution is, in fact, an interracial exchange of differences (écart différentiel). ${ }^{26}$ The French word écart also signifies an exchange of cards in a game. In the game of tropism, the rule of tolerance does not stipulate which racial signs require a tolerant reading; the cards of the game must remain random and arbitrary.

The rule of tolerance regulates tropism without being transcendent in relation to it. The rule is not "above" the game it describes, it is an immanent part of it. Tolerance is built into Lévi-Strauss' text in a way that makes the game, i.e. scientific activity and tropism, impossible without observing the rule. Contempt of the rule signifies exit from scientific truth.

Quand on cherche à caractériser les races biologiques par des propriétés psychologiques particulières, on s'écarte autant de la vérité scientifique en les définissant de façon positive que négative. [When attempting to characterize the biological races by specific psychological properties, one strays just as much from scientific truth in defining them positively as negatively..$^{27}$

The rule of tolerance does not draw a clear dividing line between the permitted and the forbidden because it is immanent in the game. One can disregard the rule but not violate it. In other words, transgression in the form of racist intolerance is inconceivable within tropism because the rule does not pronounce a moral verdict. The text demonstrates this in the apology of racist anthropology and popular prejudices: intolerance is "naive", "ignorant", "simplistic" and "pseudo-scientific" but never explicitly wrong in the moral sense of the word. The rule of tolerance is not interested in condemnation, it merely wishes to secure the continuity of the game. This game -

24 AS, 411-413; SA, 353-355.

25 AS, 377; SA, 323.

26 AS, 417; SA, 358. The English translation for écart différentiel is given as "contrastive features".

27 AS, 377 [emphasis added]; SA, 323-324. 
unlike the text's conception of history - is clearly cumulative.

The tropism the text represents is, no doubt, a sequence of scientific authors in a cumulative game. But the rule of tolerance itself requires no authorization. Both the author and the formulation of the rule are insignificant. The text situates the rule in temporal obscurity by designating the intolerance of a distant predecessor as an "intellectual error." 28 An error can only mean that the unobserved rule was already present but remained unobserved. Since the predecessor is the "father of racist theories", ${ }^{29}$ the rule must precede the original insemination. On the other hand, the manifestation of intolerance in major ethnological texts is done away with as naiveté and "total ignorance". ${ }^{30}$ This exclusion of the ignorant child from the game of tropism emphasizes that the rule of tolerance is not open for imaginative interpretation. If interpretation is ruled out, the formulation must be irrelevant. Being morally neutral, the rule of tolerance cannot prohibit intolerant conduct. It can only appeal for tolerance because disobeying the rule leads to expulsion from the game, from tropism and scientific activity.

The rule of tolerance binds the subject and the other race together in a dual relationship where both presuppose each other. The rule does not perform a distinction between the two parties. In addition, the rule requires merely unilateral tolerance. The text, expressing the feeling of gratitude and humility for the contributions of the other race, states that the beneficiary of the contribution cannot be a world civilization. ${ }^{31}$ How should one, then, understand the "common patrimony" mentioned above? A patrimony is a paternal heritage, and since the only father mentioned in the text is an intolerant scientist, it would seem that the beneficiary can only be a descendant in the scientific family line, Lévi-Strauss himself. Therefore, tolerance is not displayed by recognizing the contributions of the other race to a common heritage but by accepting, albeit gratefully and with humiliation, the donor's tribute, a tribal tax. The rule of tolerance does not contest the existing privileges of the scientific subject and establish cultural equality. Its sole aim is to secure the

29 AS, 377; SA, 324.

30 AS, 405; SA, 348.

31 AS, 416; SA, 357-358. 
continuity of the tropistic game and its requirements.

Notwithstanding the securing of this continuity, the rule of tolerance does not have further objectives of a politico-moral nature. The essential topic of Lévi-Strauss' text is racial tolerance displayed in scientific knowledge, and only at the closing pages does the text mention a "sacred obligation of humanity" to promote tolerance. Curiously enough, it is exactly the same place where the text ceases to speak of scientific enterprise and its own commitments. At this point, the text quite innocently transforms itself into a delegation of regulative intentions from science to international institutions ${ }^{32}$ The reason for this is the inability of tropism to confront intolerant behaviour outside its own game. As the transgression of the rule of tolerance is inconceivable, the racist counterpart of tropism suggests a form of intolerance regulated by a similar normative logic. This would require adherence to another rule, a rule of intolerance. It is a ceremonial variant of racism and is perhaps best illustrated by the activities of the Ku Klux Klan in the United States and the violent youth gangs of contemporary Europe. But the rules of intolerance and tolerance cannot be juxtaposed as they are two different games, they are of a different order. In both tropism and ceremonial racism, breaking the rule merely expels one from the game without moral condemnation. And, as contradictory as it may seem, the ceremonial is also the normal. Just as in ceremonial racist violence, the logic of a rule dictates the structures of the most common and everyday forms of racist intolerance: offending humour, membership criteria of social organizations, the cultural depreciation of nonEuropean civilizations, the taboos of interracial sexuality, etc.

\section{The Politician and the Law of Tolerance}

If Lévi-Strauss' text delegates the objective of confronting racism to international institutions, it must also presume another variant of racial tolerance, advocation $n^{33}$ or a political axiology based on legal

32 AS, 420; SA, 361.

33 Advocation or advocacy is here derived from advocare, to avow, to call or summon for assistance. It is used to describe both the action of the avowed and the advowee. John Burke (ed.), Jowitts Dictionary of English Law.Volume 1 ( $A-K$ ) (London: Sweet and Maxwell Limited, 1977), 63. 
equality. Advocation is the subject's political activity on behalf of the other race concerning the latter's political rights and freedoms. The International Convention on the Elimination of All Forms of Racial Discrimination ${ }^{34}$ states its advocatory intentions:

States Parties shall ... take, in the social, economic, cultural and other fields, special and concrete measures to ensure the adequate development and protection of certain racial groups or individuals belonging to them ...35

In other words, the Convention stipulates an obligation for State Parties - the subject - to act on behalf of unnamed racial groups who can only be identified by a certain level of underdevelopment. Social, economic and cultural underdevelopment becomes the signifying element that distinguishes the subject from the other race. The common denominator of interracial comparison in advocation is social, economic and cultural progress, an evolutionary scale. An emphasis on the economic is conspicuous. The text of the Convention defines economic rights by way of work.

... the right to work, to free choice of employment, to just and favourable conditions of work, to protection against unemployment, to equal pay for equal work, to just and favourable remuneration ...36

The right to work also presumes an obligation of labour in exchange for the evolution from economic underdevelopment to the status of a full subject. Racial tolerance is displayed by defining this right/obligation as just, as binding to all "without distinction of any kind, in particular as to race, colour or origin." The free choice of employment does not grant the possibility of evading this obligation; it merely states that there are options between numerous employers. By operating with bilateral rights and obligations, the text of the Convention presumes that favourable working conditions secure maximum efficiency for the benefit of all concerned.

In political advocation, the relationship between the subject and the other race is based on equivalence, not analogy. The subject and the other do not resemble each other as ontological beings but as values. The axiological scale of equivalent values is constituted in

United Nations General Assembly Resolution 2106 A (XX) of 21 December 1965.

35 Article 2.2.

36 Article 5. 
the market. The political movement for the abolition of slavery, for example, would accordingly be founded on the idea that the subject and the other race were comparable as to their market value in production. The injustice of slavery was evident in the improper and intolerant evaluation of the slave's work in the market. The Convention's jargon about economic development implies, albeit in a very tolerant manner, that the foundation of racially significant injustice is also due to erroneous market evaluations. If the subject is the only party to receive profits, the economic potential of the other race must either be abused or it has not been properly put to use. The subject represents a more or less balanced value in an ideal market situation while the other race, requiring "adequate development and protection", suffers from certain shortcomings.

In an analogical relationship, the other race is enigmatic and alluring because the subject's capacity to know is necessarily limited. In an equivalent relationship, the subject knows everything. The other race is as valuable as its potential efficiency on the market but, on the other hand, its ability to provoke ontological questions is worthless. In its lengthy Preamble, the text of the Convention parades the unlimited comprehension and knowledge of the advocatory subject. It acts tolerantly "considering" the context, it is "convinced" and "alarmed" by the problem of racism and its causes, it "reaffirms" the just nature of its own political conviction, it is "resolved" to act. But as the Convention is open for signature, ${ }^{37}$ it is not exactly clear who the advocatory subject is. If work and production form a single scale of evaluation, the subject and the other race are not as distinguishable as before. The analogical relationship never questioned the significant difference between the subject and the other race while the equivalent relationship already establishes a profound resemblance.

As an analogy of the subject, the other race was also singular and unique. As an equivalent of the subject, it is plural and standard. The text of the Convention defines the standard as a collection of guaranteed rights "without distinction as to race, colour, or national or ethnic origin." 38 The tropistic curiosity of exploring the specific characteristics of a singular people, that is, making distinctions as 
to race, colour, and national or ethnic origin, is replaced with a political advocation relying on demographic generalizations the ultimate aim of which is a "new economic world order".

The normative logic of the anti-racist principle is obviously quite different in advocation: it follows the logic of a law. Unlike the rule, the law of tolerance must explicitly designate the signs that the subject should heed in order to deem an action tolerant in the advocatory sense of the word. The Convention is no game; it is an agreement, a fixed fight that intentionally delineates the possibilities of hazard and chance. The text must, accordingly, come to an agreement on the signs that are to be taken into consideration in advocation. The Convention must itself, by way of negation, list the variables that are to be respected in racial tolerance:

... race, colour, descent, or national or ethnic origin which has the purpose or effect of nullifying or impairing the recognition, enjoyment or exercise, on an equal footing, of human rights and fundamental freedoms in the political, economic, social, cultural or any other field of public life. ${ }^{39}$

This meticulous specification of signs suggests that the law of tolerance is transcendent in relation to the behaviour it regulates, it is "above" advocation. Unlike the immanent rule, the transcendent law both commands and prohibits. In other words, the law encompasses both lawful and unlawful behaviour, both tolerance and intolerance. As a law, the text of the Convention first establishes a punitive procedure with which State Parties must "undertake to pursue by all appropriate means ... a policy of eliminating racial discrimination in all its forms." 40 Secondly, the text of the Convention obliges State Parties to promote institutional support for tolerant behaviour. ${ }^{41}$ The rule was valid for one game only, but the law of tolerance both requires tolerance and condemns intolerance and in doing so states its intention of regulating racial thought in general.

The transcendence of the law in relation to advocation draws the dividing line between the permitted and the forbidden which was the prerequisite for breaking the law, for transgression. In other words, intolerance as transgression is possible providing that the

39 Article 1.1.

40 Articles 2.1 and 4.

41 Article 7. 
anti-racist principle requiring tolerance is by nature a law. Both tolerance and intolerance are thus acted out on the same terrain governed by a single law.

Unlike in tropism, the law of tolerance in advocation presupposes a law-giver whose identity is never insignificant. Most of the Convention's Preamble is dedicated to emphasizing that the advocatory agreement has been reached under the auspices of the United Nations. If the text itself possessed sufficient mandatory power, this emphasis would be pointless. The law of tolerance, however, requires a contextual author, an outside authority to furnish the text with coercive force. The law of tolerance must encompass behaviour that is, strictly speaking, outside its own jurisdiction. As an agreement, the Convention is only a promise given by the agreeing parties, but as a law, it must also evaluate the conduct of those who have never committed themselves to it. In addition, the law of tolerance is open for interpretation. Advocation is often precisely the presentation and justification of tolerant interpretations of the law, and the text of the Convention reaffirms this possibility by specifically ruling out interpretations of an intolerant nature. ${ }^{42}$

As a law, the ratified Convention bears a certain date of entering into force. ${ }^{43}$ This implies that the law of tolerance is valid only from a certain time. The law of tolerance that the text of the Convention represents is, however, explicitly announced as universal. ${ }^{44}$ Despite its extensive and minute formulations of procedures of validation, the Convention only briefly touches on the possibility of invalidation after the ratification of the law. ${ }^{45}$ Hence, the temporal dimension of jurisdiction is more or less left open concerning both the past and the future. Because the law of tolerance both commands and prohibits, one cannot, as in a game, escape the spatial dimension of jurisdiction by violating the law. It would seem that even by resisting ratification of the Convention, a State Party or any nonagreeing outsider is transgressing the law. This absurd generality gives the law of tolerance the universality of a natural law.

The law of tolerance establishes an equality of a legal nature 
between the subject and the other race. But before doing so, the law must first make a distinction. As the subject and the other race are equivalent in advocation, there is, strictly speaking, only one party. The only way to accomplish the distinction between the two parties is to identify the discriminated. Regardless of its benevolent intentions, the law of tolerance must itself perform a discriminatory act. The text of the Convention must do what it prohibits, namely, make a distinction between "human beings" "as to race, colour, or national or ethnic origin". After the distinction is made, the law of tolerance binds the subject and the other race in a cohesive fashion: tolerance requires reciprocal tolerance. The text itself anticipates the rhetorical potential of this reciprocality by regulating the procedures of dispute. ${ }^{46}$

Unlike the rule, the law of tolerance has a far more important objective than the regulation of racial relationships. Tolerance is not even the primary objective of the law. The telos of the law of tolerance is a political project, interracial brotherhood:

... discrimination between human beings on the grounds of race, colour or ethnic origin is an obstacle to friendly and peaceful relations among nations and is capable of disturbing peace and security among peoples ... the existence of racial barriers is repugnant to the ideals of any human society ...47

The renowned inefficiency of international conventions in regulating everyday life is based on yet another problem of correlation. The logical intolerant counterpart of advocation is a political variant of racism such as South African apartheid, and conventions and agreements have, no doubt, demonstrated their relative usefulness in regulating it. But if everyday intolerance, the normal and commonplace aspect of racism, is of a ceremonial nature, it is regulated by a rule of intolerance. Once again we encounter the problem of juxtaposition: a law is irrelevant in relation to behaviour regulated by a rule. As long as the spell of the racist game lasts, the law is powerless. And yet, the racial tolerance exhibited in everyday lives must be guided by some normative element. 


\section{The Humanist and the Norm of Tolerance}

The rules and laws of tropism and advocation may be inadequate in regulating intolerance, but the extent of racial respect in contemporary society must imply that something or other governs racial thought in the Western world. This third variant of racial tolerance, the tolerant counterpart of our intolerant starting point, is globalism or a pseudo-axiology based on the ideal of communitarian humanism. Globalism is perhaps best portrayed in the ability of the advertising industry to annul the signs of racial difference. During the last few years, the trademark Benetton has illustrated this globalism in their advertising campaign picturing the races of the world together dressed in uniform clothing. ${ }^{48}$ In the globalism of Benetton, the other race is not merely a "brother" in the meaning of the Universal Declaration of Human Rights. The subject and the other race are family in a considerably more literal sense: they are homogeneous, they originate from the same gene, they are identical twins.

Globalism renders the other race into a perfect simulation of the subject. They can be told apart only by a structural difference which is altogether neutral and formal. Therefore, the scale of evaluation is pseudo-axiological and the races invaluable in the literal meaning of the word. The operational and digital logic of structuralistic oppositions eliminates all myths of origin and the remaining inequalities in racial relationships. The black, white, yellow and red races of the Benetton campaign are as indistinguishable as the brilliant garments: they are clones of a single model and can be told apart only by a formal cryptogram known solely to the Creator. In its campaign, Benetton has never differentiated its merchandise by naming specific models. The races also remain unnamed, and without a name, subjectivity and otherness as a structure of identity is inconceivable. At last, tolerance is comprehensive!

In tropism, the tolerance of the subject was triggered by scientific curiosity, the fascination of the game, whereas the advocatory subject was more like a Pavlovian dog, a political animal conditioned to react to the stimulus of abnormal market situations. What, then, motivates the subject in globalism? The cultural logic of globalism

48 E.g., United Colors of Benetton, product catalogue, Spring 1991, photographs by O. Toscani (Milano: Amilcare Pizzi, 1990). 
has been accurately described by Jean Baudrillard. ${ }^{49}$ As the encompassing globalism begins to abolish differences, the subject faces a dilemma. In a homogeneous world, there are no differences to tolerate or discriminate. On the other hand, the subject can no longer find the limits necessary for the original distinction or its own subjectivity. As the subject is fading into oblivion, a panic reaction follows. The subject commences to produce new differences in order to save itself and the other race from the terror of simulation. The schizophrenic frenzy of globalism is the compulsion to be simultaneously the same and different.

This is the core of our problem: otherness and difference are not akin. In the relationship between the subject and the other race, otherness signifies the radical dissimilarity that can never be overcome. Otherness is conspicuous in, for example, the striking disinterest of non-Occidental civilizations regarding the cultural traits of the European world. The other will always be incomprehensible, and cultural identity requires that it remain so. Difference, on the other hand, is concurrent similarity and dissimilarity, inclusion and exclusion. Occidental racial tolerance is never founded on otherness, it is always a discourse on difference: the other race is the same and different, recognized and discriminated. As the compulsion to tolerate draws the other race closer and closer, it reaches a point where all differences have been done away with. The tolerance of globalism manifests this hyper-resemblance in its anti-racist principle. It proclaims the universal right to be different in its beautiful slogan: "We are all different". At the same time, it must acknowledge the universality of difference: "In our difference, we are all the same". The universal right to difference is embodied in Benetton's metaphoric reference to form of government: the right to difference is the essential content of the Constitution of the "United Colours of Benetton".

In globalism, the constitutional right of difference is present in numerous phenomena of contemporary everyday life: Nicaraguan coffee, Vietnamese take-away, Live Aid, Algerian wine, Indian cotton, Afghanistan hashish, Turkish delight, Kama Sutra, Zen, Argentine tango. The humanist of globalism understands the world extrêmes (Paris: Galilée, 1989), 129-143. 
as a collection of human accomplishments that the subject must learn to respect as its own. Intolerant universality is finding the latent presence of the subject when it is manifestly absent in the other race, taking difference for deficiency..$^{50}$ The tolerance of globalism, on the other hand, interprets the difference of the other race as something that the subject does not possess. Although the defect has been turned around, the entity the difference represents is, however, an unquestionable phenomenon in a universal world.

In this tolerant universality, the anti-racist principle proclaiming the constitutional right to difference and guiding the subject to acquire and interject the difference of the other race into its own life is a norm. The norm of tolerance, unlike the rule or the law, does not require observation, nor does it command or prohibit. It functions by way of supervision, deterrence, dissuasion and persuasion. The subject displays its tolerance by integrating the difference in a situation that is not obliging.

Ceaselessly and compellingly producing new differences to tolerate and integrate, globalism homogenizes the world until it is totally universal. Born of the same gene, the other race comes dangerously close. Thus, the tolerance of globalism accelerates the very logic of racist intolerance itself. If the other race is the other, that is, radically different, singular, incomprehensible and unattainable, the subject has nothing to fear. But once the world has been homogenized, the compulsory production of differences necessarily takes on a racist form: "I am not the other!" 51 The indistinguishability of homogeneous clones is, in the end, confronted with the ultimate metaphor of racism. An "alien" may have once been merely illegal, but Baudrillard correctly notes that today it is also a viral monster that spreads into society by reproducing itself like HIV. The viral metaphor has always served as the essence of racist theories such as $\mathrm{Zi}$ onist conspiracy and, more lately, the rise of the Islamic world. The other race incubates in the healthy organs of humanism, but even-

50 On the technique of universalization, see, e.g., Giles Deleuze and Félix Guattari, Capitalisme et schizophrénie. Anti-Oedipe, (Paris: Gallimard, 1972), 202.

51 This strange fluctuation between the self and the other resembles what Foucault describes as the dialectic of sympathy and antipathy. Michel Foucault, Les mots et les choses. Une archéologie des sciences humaines (Paris: Gallimard, 1966), 38-40. 
tually it will hatch and, in doing so, terminate the life of its host.

\section{Illiteracy}

This acceleration is the key to Baudrillard's critique of racial tolerance. Even though the critique of racism has confirmed the fallacy of the biological foundation of discrimination, racism has not made way for a tolerant form of interracial relations. Quite the contrary, racism has fragmented into small and isolated forms of everyday incidents that the latest form of tolerance, globalism, seems only to accelerate. A uniform critique of this fragmented normality is impossible. The critique presented in the name of racial tolerance is always formal in that it only touches the surface. This is why racism outlives its critique. Critique may have proven the biological fallacy of discrimination, but it has never discredited racial biology. Critique may have touched upon the racist obsession of difference, but it has not indicated the hazardous logic of difference itself. Racial tolerance is a dream of using the logic of difference for benevolent purposes, but difference will always lead straight back to racism. This is why the West must rediscover the other, the radically different.

Occidental anti-racist critique considers the universal recognition of human rights as a victory of the other race. But it is, of course, an Occidental triumph. The entire world has recognized the universality of Occidental values. The victory of the rest of the world can be seen in the vulnerability and helplessness of the Occidental world when confronted by phenomena such as world culture. But the mysteries of the New World are no secret because no one hides the answer. On the contrary, through its cultural exchange programmes, the Occident spends enormous amounts of money to import answers for all to inspect, to understand. But it is unable to read the answer. All analysis and reasoning leads to new questions until, in the end, these questions turn into a doubt and a critique of the subject's own culture. This culture, tormented by its sense of inferiority and illiteracy, constitutes the last primitive people of this world. 